\title{
Intercalated Duct of the Salivary Gland System
}

National Cancer Institute

\section{Source}

National Cancer Institute. Intercalated Duct of the Salivary Gland System. NCI Thesaurus.

Code C49266.

The tiny tubules with a very thin epithelial layer in the salivary glands running from the salivary acini into the striated duct. 